\title{
Changes in physiological and behavioral parameters of preterm infants undergoing body hygiene: a systematic review
}

\author{
VARIAÇÕES NOS PARÂMETROS FISIOLÓGICOS E COMPORTAMENTAIS DE RECÉM- \\ NASCIDOS PRÉ-TERMO SUBMETIDOS À HIGIENIZAÇÃO CORPORAL: REVISÃO SISTEMÁTICA
}

\author{
LAS VARIACIONES DE LOS PARÁMETROS FISIOLÓGICOS Y DE COMPORTAMIENTO DE LOS \\ RECIÉN NACIDOS PRETÉRMINOS SOMETIDOS A BAÑO DE INMERSIÓN: \\ UNA REVISIÓN SISTEMÁTICA
}

\section{Patrícia de Freitas ${ }^{1}$, Silvia Rezende Marques², Taisy Bezerra Alves ${ }^{3}$, Juliana Takahashi ${ }^{4}$ Amélia Fumiko Kimura ${ }^{5}$}

\begin{abstract}
Objective: To verify the effect of bathing on the body temperature of preterm infants (PTI). Method: Systematic review conducted in the following bibliographic electronic sources: Biblioteca Virtual em Saúde/Lilacs (BVS), Cumulated Index of Nursing and Allied Health Literature (CINAHL), Cochrane Library, Google Scholar, PubMed, SCOPUS and Web of Science, using a combination of search terms, keywords and free terms. The review question was adjusted to the PICO acronym (Patient/population, Intervention, Control/comparative intervention, Outcome). The selected publications were evaluated according to levels of evidence and grades of recommendation for efficacy/effectiveness studies, as established by the Joanna Briggs Institute. Results: Eight hundred and twenty four (824) publications were identified and four studies met the inclusion criteria, of which three analyzed the effect of sponge baths and the effect of immersion baths. Conclusion: Sponge baths showed a statistically significant drop in body temperature, while in immersion baths the body temperature remained stable, although they studied late preterm infants.
\end{abstract}

\section{DESCRIPTORS}

Baths

Premature

Body temperature

Neonatal nursing

Review

\section{RESUMO}

Objetivo: Verificar o efeito do banho na temperatura corporal de recém-nascidos pré-termo (RNPT). Método: Revisão sistemática realizada nas fontes eletrônicas bibliográficas BVS/Lilacs, Cumulative Index of Nursing and Allied Health (CINAHL), Cochrane Library, Google Scholar, PubMed, SCOPUS e Web of Science, utilizando a combinação de descritores, palavras-chave e termos livres. A pergunta da revisão foi ajustada ao acrônimo PICO (Paciente/ população, Intervenção, Intervenção controle/comparativa, Desfecho analisado). As publicações selecionadas foram avaliadas de acordo com os níveis de evidência e graus de recomendação para estudos de eficácia/efetividade estabelecidos pelo Instituto Joanna Briggs. Resultados: Foram identificadas 824 publicações e quatro estudos atenderam aos critérios de inclusão, dos quais três analisaram o efeito do banho de esponja e um o efeito do banho de imersão. Conclusão: O banho de esponja mostrou queda da temperatura corporal estatisticamente significante, enquanto no banho de imersão a temperatura corporal permaneceu estável, embora tenham sido estudados RNPT tardios.

\section{DESCRITORES \\ Banhos \\ Prematuro \\ Temperatura corporal \\ Enfermagem neonatal \\ Revisão}

\begin{abstract}
RESUMEN ros tardíos.

\section{DESCRIPTORES \\ Baños \\ Prematuro \\ Enfermería neonatal \\ Revisión}

Temperatura corporal
\end{abstract}

Objetivo: Determinar el efecto del baño en la temperatura corporal del recién nacido prematuro. Método: Revisión sistemática realizada en las fuentes bibliográficas electrónicas BVS, CINAHL, Cochrane Library, Google Scholar, PubMed, Scopus y Web of Science. Las búsquedas fueron realizadas mediante combinación de descriptores, palabras clave y términos libres y se ajustó la cuestión de la revisión a la estrategia PICO. Las publicaciones seleccionadas se evaluaron de acuerdo con los niveles de evidencia y grados de recomendación para los estudios de eficacia/efetividad establecidos por el Instituto Joanna Briggs. Resultados: Se identificaron 824 publicaciones y cuatro atendieron a los criterios de inclusión, de los cuales, tres analizaron el efecto del baño de esponja y uno el efecto del baño de inmersión. Conclusión: El baño de esponja mostró una disminución estadísticamente significativa en la temperatura corporal, en cuanto que el baño de inmersión, la temperatura corporal se mantuvo estable, aunque el estudio haya sido realizado con recién nacidos prematu-

${ }^{1}$ Doctoral Student, School of Nursing, University of São Paulo, São Paulo - São Paulo, Brazil. ${ }^{2}$ Undergraduate Nursing Student, School of Nursing, University of São Paulo, São Paulo - São Paulo, Brazil. ${ }^{3}$ Master's Degree Student, School of Nursing of the University of São Paulo, São Paulo - São Paulo, Brazil. ${ }^{4}$ Librarian, School of Nursing, University of São Paulo, São Paulo - São Paulo, Brazil. ${ }^{5}$ Ph.D. Professor, Department of Maternal-Infant and Psychiatric Nursing, School of Nursing, University of São Paulo, São Paulo - São Paulo, Brazil. 


\section{INTRODUCTION}

In Brazil, in 2010, the number of births of preterm infants (PTI) with a gestational age (GA) between 22 and 36 weeks was 201,929, representing $7 \%$ of total births ${ }^{(1-2)}$. This population presents anatomical and functional immaturity of various organs and systems, requiring special care in the early stages of life, the objective being their healthy growth and development ${ }^{(3)}$.

The nursing care administered to this population is considered to be a stress factor, generating a significant impact on child development ${ }^{(4)}$. Among the care actions taken, immersion baths are characterized by certain handling methods that provide a series of exchanges and interactional adjustments between caregivers and newborns (NB), which may potentially reveal the characteristics of the reaction of newborns and the appropriateness of the procedure(1).

Baths, like any other procedures that involves intense handling, create disorganization and stress for newborns; the lower the GA, the greater the impact, affecting the stability of physiological and behavioral parameters ${ }^{(5-6)}$.

In Brazil, the cleansing technique (hygiene) most commonly adopted in neonatal wards is immersion baths, followed by cleaning of the bodies of the infants in the incubators. The technical manual Humanized Care for the Low-Weight Newborn -- Kangaroo Mother Model, published by the Ministry of Health, recommends that bath be performed by the mother of the newborn and the infant to be immersed in water while wrapped in a towel or diaper, being gradually withdrawn as the parts of the body are washed $^{(1)}$.

Particularly in moderate and extreme preterm infants, the term of the regulatory mechanisms are easily overlapped, leading to metabolic deterioration and death from hypothermia or other associated causes such as serious infections ${ }^{(7)}$.

The principle adopted when conducting nursing care in neonatal intensive care units is to provide conditions for stabilization of physiological states, minimizing stress factors for newborns.

While body cleaning is a routine procedure in neonatal units, we question the effects on stability of body temperature for preterm infants undergoing this procedure.

The aim of the study was to verify the effect of baths on the body temperature of preterm infants undergoing the procedure.

\section{METHOD}

This was a systematic review that examined changes in body temperature of preterm infants exposed to body hygiene.
In all areas of health care there has been a progressive increase in scientific production. In this sense, systematic reviews are tools for identifying the best scientific evidence that may be incorporated into the practice of professionals when providing healthcare services and education, conducting management and formulating healthcare policies ${ }^{(8)}$.

The question that guided this review was: Are there variations in the body temperature of preterm infants exposed to bathing or body hygiene?

The question was adjusted to the PICO acronym, for compiling the bibliographic search, with $P$ (population/ patient/participants) representing the preterm infant; I (intervention/procedure) the procedure of body hygiene; $\mathrm{C}$ was assigned to the comparative intervention, the control group in this review that corresponded to the control intervention, to the placebo treatment or non-existence of the comparison group; and $O$ represented the outcomes of interest for this review, changes in body temperature.

The publications were identified in the following electronic sources: Biblioteca Virtual em Saúde (BVS) that include database Lilacs, Cumulative Index of Nursing and Allied Health Literature (CINAHL), Cochrane Library, Medical Publications (PubMed), Scopus and Web of Science, as well as in the Google Scholar academic search engine for the search for gray literature, after defining the keywords beforehand. The search in the sources was carried out from December 26, 2013 to January 15, 2014. The bibliographic survey encompassed publications indexed in these electronic bibliographic databases, without imposing restrictions on the publication date. In the initial search of the publications, the following free terms were used: bath, premature infant, body temperature control, adaptation, traditional bath, sponge bath, and tub bath. The Boolean operators and, or and not were used in the combination of the search terms, when performing searches. The identified publications were analyzed in order to refine the search terms, keywords and free terms.

In addition to the free terms mentioned, search strategies were elaborated with the assistance of the librarian at the School of Nursing of the University of São Paulo, combining keywords for the intervention of interest (bathing, body hygiene) with search terms or keywords for the type of participants (preterm infant newborn). The search terms were located with the aid of the DeCS tool, available in the electronic database of the BVS, and the $\mathrm{MeSH}$ tool, from the PubMed electronic database.

The combination of free terms and search terms identified in the PICO strategy was carried out by way of the Boolean operators or and and. In this manner three maps of search strategies were defined, with 21 different combinations of terms, search terms and keywords. 
The inclusion criteria for the systematic review of publications were studies with a sample of PTI with the following study designs: systematic review with and without meta-analysis, clinical trials, quasi-experimental, cohort, case-control and cross-sectional.

From the analysis of the abstracts, which was performed by two reviewers, publications were organized and divided into three groups: Probable inclusion, not included and to be determined, according to whether they were in accordance with the inclusion criteria of the review or not. Abstracts classified as probable inclusion and those to be determined were analyzed in their entirety. Publications that met the eligibility criteria and responded to the question formulated initially comprised this systematic review.

The publications were grouped according to the outcome variations in body temperature. The studies were categorized according to levels of evidence and grades of recommendation for efficacy/effectiveness studies, based on the classification system of the Joanna Briggs Institute, adopted as of March 2014 ${ }^{(8)}$ : Level 1 - Design of the experimental research: 1 .a - Systematic review of randomized controlled trials; $1 . b$-Systematic review of randomized controlled trials and other study designs; 1.c - Randomized controlled trials; $1 . d$ - Pseudo-randomized controlled trials. Level 2 - Quasi-experimental designs: 2.a - Systematic review of quasi-experimental studies; 2.b - Systematic review of quasi-experimental and other study designs with less evidence; 2.c - Studies prospectively controlled for quasi-experiments; 2.d - Pre-test and post-test studies or retrospective controlled historical groups. Level 3 - Observational analytical designs: 3.a - Systematic review of studies of comparable cohorts; 3.b - Systematic review of comparable cohorts and other study designs with less evidence; 3.c - Cohort studies with a control group; 3.d - Case-control studies; 3.e - Observational studies without a control group. Level 4 - Observational - descriptive studies: 4.a - Systematic review of descriptive studies; 4.b - Cross-sectional studies; 4.c - Case series; 4.d - Case Studies. Level 5 - Expert Opinion - Bench research performed in laboratory: 5.a - A systematic review of expert opinions; 5.b - Expert consensus; 5.c - Bench research, in laboratory/expert opinions.

Grades of recommendation for reviews of studies of effectiveness ${ }^{(9)}$ : Grade A - Strong recommendation for the adoption of a management strategy for health care: (1) the desirable effects are clear, and outweigh the undesirable effects; (2) there is evidence of adequate quality to support its use; (3) there are benefits without impact on resources used; and (4) the values, preferences and experiences of the patients have been taken into account. Grade B - A weak recommendation for a certain health management strategy where: (1) desirable effects appear to outweigh undesirable effects of the strategy, although this is not as clear; (2) there is evidence supporting its use, although this may not be of high quality; (3) there is a benefit, no impact or minimal impact on resource use; and (4) values, preferences and the patient experience may or may not have been taken into account.

Considering that in the current grades of recommendation there is no classification for studies which have effects that outweigh benefits in healthcare intervention strategies, in this review we adopted the term not recommended for the studies that were found to be in this situation. The strength of the recommendation of the efficacy/effectiveness was classified by answering the following questions: 1 . Was the effect beneficial? and 2. Was the procedure (intervention) safe? ${ }^{(9)}$

\section{RESULTS}

Figure 1 shows the flow of the publications included in this systematic review following the recommendations of the Preferred Reporting Items for Systematic Reviews and Meta-Analyses (PRISMA) ${ }^{(10)}$.

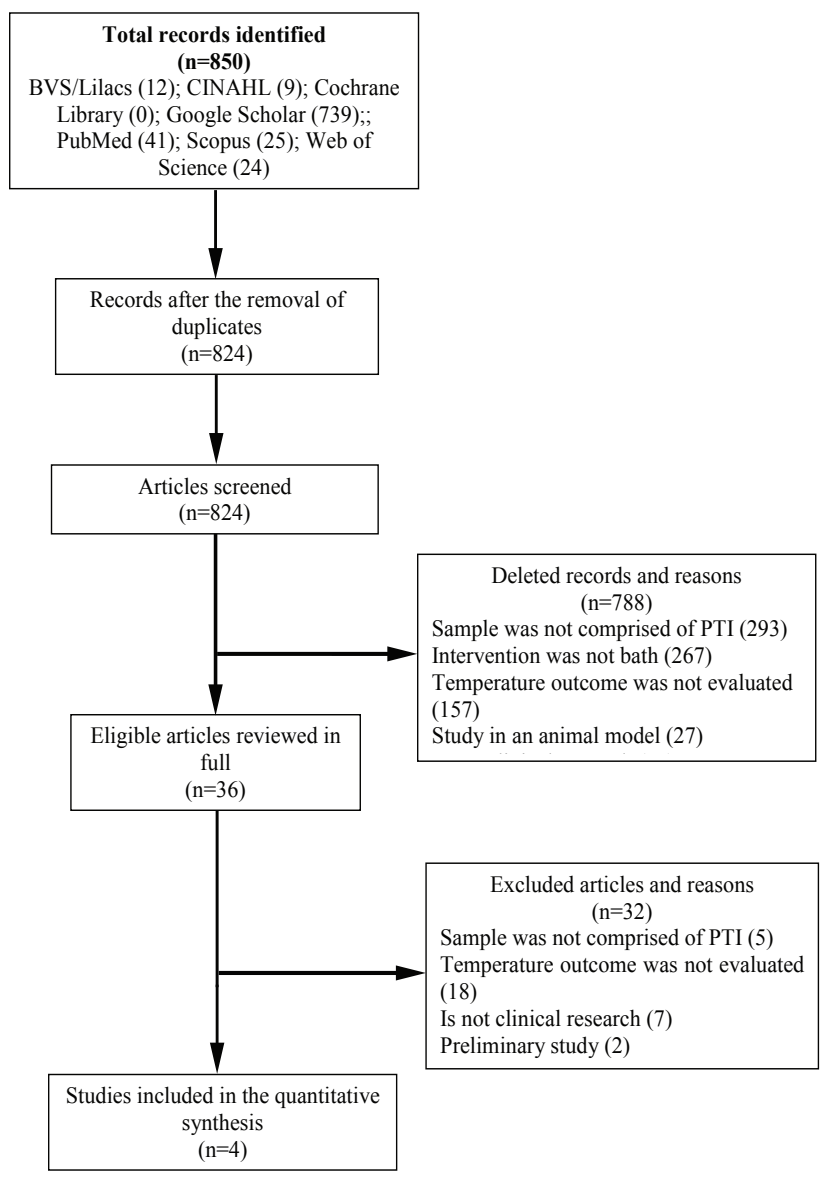

Figure 1 - Flow of the publications identified, analyzed and included in the review - São Paulo, 2014

Table 1 presents the selected studies regarding the effects of bathing in terms of the stability of temperature in $\mathrm{PTI}$. 
Table 1 - Identification of the study, authors, year of publication, population/sample, type of bath that the newborns were exposed to, effect of the bath on body temperature, study design, level of evidence, grade of recommendation, benefit and safety - São Paulo, 2014

\begin{tabular}{|c|c|c|}
\hline ID) Author (Year) Sample & Type of Bath - Effect of the Bath on Body Temperature & $\begin{array}{l}\text { Design/Level of Evidence Grade of } \\
\text { Recommendation Benefit/Safety }\end{array}$ \\
\hline $\begin{array}{l}\text { E1) Tapia-Rombo et al. }(2003)^{(11)} \\
79 \text { NB } \\
\text { GA } \geq 28 \leq 36 \text { weeks (wk) }\end{array}$ & $\begin{array}{l}\text { Sponge baths: Newborns weighing }<1,800 \mathrm{~g} \text { underwent baths } \\
\text { in incubators and }>1,800 \mathrm{~g} \text { underwent baths outside incubators. } \\
\text { There was no statistical difference in body temperature (rectal) } \\
\text { before and after sponge baths. The mean temperatures were } \\
37^{\circ} \mathrm{C} \text { before and } 36.5^{\circ} \mathrm{C} \text { after, } \mathrm{p}<0.0001 \text {, regardless of the } \\
\text { location and weight of baths. }\end{array}$ & $\begin{array}{l}\text { Prospective quasi experimental } / 2 . c \text { Not } \\
\text { recommended Not beneficial, unsafe }\end{array}$ \\
\hline $\begin{array}{l}\text { E2) Montes Bueno et al. }(2005)^{(12)} \\
\mathbf{2 6} \text { NB } \\
\text { Weight } \geq 500 \mathrm{~g} \leq 1,000 \text { grams (g) }\end{array}$ & $\begin{array}{l}\text { Sponge baths: The central temperatures (axillary) and } \\
\text { peripheral (sole) were measured continuously before, during } \\
\text { and after (during } 180 \text { minutes) washing of the body. Baths was } \\
\text { performed with the infants in incubators. The body temperatures } \\
\text { obtained in the first week of life were compared with those of } \\
\text { the second week of life. There was a significant decrease in } \\
\text { axillary and sole temperatures after washing in comparison } \\
\text { to the temperature before, p }<0.001 \text {. Sponge baths caused a } \\
\text { decrease in axillary temperature, with a temperature below } 36.5 \\
{ }^{\circ} \mathrm{C} \text { in } 87.4 \% \text { of the newborns and below } 36^{\circ} \mathrm{C} \text { in } 45.5 \% \text {. The } \\
\text { average axillary temperature remained below } 36.5^{\circ} \mathrm{C} \text { for more } \\
\text { than an hour, in the first week of life, and for an hour in the } \\
\text { second week of life. The temperature difference before and after } \\
\text { baths was greater than } 1{ }^{\circ} \mathrm{C} \text {, in the first and second weeks of life. }\end{array}$ & $\begin{array}{l}\text { Observational without control group } / 3 \text {.e } \\
\text { Not recommended Not beneficial, unsafe }\end{array}$ \\
\hline $\begin{array}{l}\text { E3) Loring et al. }(2012)^{(5)} \\
\text { 100 NB } \\
\text { GA } \geq 35<37 \text { without } \\
\text { weight }>2,000 \mathrm{~g} \\
\text { Age } \geq 4 \text { hours } \leq 36 \text { hours of life }\end{array}$ & $\begin{array}{l}\text { Immersion baths: Compared the body temperature to those } \\
\text { receiving sponge baths (control group). Axillary temperature } \\
\text { was measured } 10 \text { minutes before and } 10 \text { and } 30 \text { minutes } \\
\text { after. The infants were randomized to receive one of two } \\
\text { types of cleansing. At } 10 \text { minutes pre-bath, the mean axillary } \\
\text { temperature in the two groups was } 98.7^{\circ} \mathrm{F}\left(37.056{ }^{\circ} \mathrm{C}\right) \text {. At } 10 \\
\text { minutes post-bath, the average temperatures showed significant } \\
\text { differences, according to the type of bath. In those exposed to } \\
\text { sponge baths, the average was } 98.164^{\circ} \mathrm{F}\left(36.758^{\circ} \mathrm{C}\right) \text {, and for } \\
\text { those who received immersion baths, } 98.322^{\circ} \mathrm{F}\left(36.846{ }^{\circ} \mathrm{C}\right) \text {, p }= \\
0.000 \text {. At } 30 \text { minutes post-bath, there was also a difference in the } \\
\text { mean axillary temperature. Among those who received sponge } \\
\text { baths, the mean was } 98.41{ }^{\circ} \mathrm{F}\left(36,894{ }^{\circ} \mathrm{C}\right) \text {, and those who were } \\
\text { immersed had a mean temperature of } 98.602{ }^{\circ} \mathrm{F}\left(37,001{ }^{\circ} \mathrm{C}\right) \text {, } \\
\mathrm{p}=0.040 \text {. The R-ANOVA test showed statistical interaction in } \\
\text { the effect between the time and the type of bath, p }=0.024 \text {. The } \\
\text { findings confirmed the hypothesis that PTI bathed by immersion } \\
\text { exhibit lower thermal variation after washing and greater post- } \\
\text { bath axillary temperature. }\end{array}$ & $\begin{array}{l}\text { Randomized clinical trial/1.c. A (1) } \\
\text { Beneficial, safe }\end{array}$ \\
\hline $\begin{array}{l}\text { E4) Tapia-Rombo et al. }(2012)^{(13)} \\
\text { 48 NB } \\
\text { ]GA } \geq 28 \leq 36 \text { without } \\
\text { weight } \geq 800 \mathrm{~g} \leq 2,770 \mathrm{~g}\end{array}$ & $\begin{array}{l}\text { Sponge bath: Rectal temperature was monitored } 10 \text { minutes } \\
\text { before washing, during and } 10 \text { minutes after. The mean } \\
\text { rectal temperature before and } 10 \text { minutes after bathing were, } \\
\text { respectively, } 37^{\circ} \mathrm{C} \text { and } 35.5^{\circ} \mathrm{C}, \mathrm{p}<0.001 \text {. }\end{array}$ & $\begin{array}{l}\text { Prospective quasi experimental } / 2 \mathrm{c} \text {. Not } \\
\text { recommended Not beneficial, unsafe }\end{array}$ \\
\hline
\end{tabular}

The data in Table 1 show that studies that analyzed the effect of sponge baths were with study designs that had lower levels of evidence and the results were not favorable for maintaining the thermal stability of PTI, indicating a drop in body temperature, and, in fact, producing a postbath effect of hypothermia (E2 and E4). Moreover, the only study that evaluated thermal stability of newborns subjected to immersion baths (E3) showed that in this method of washing PTI there was lower thermal variation between temperature measurements before and after bathing. Furthermore, the methodological design adopted was hierarchically superior to studies that analyzed body temperature with sponge baths.

\section{DISCUSSION}

The two studies conducted by the same researchers (E1) and (E4), in which post-sponge bath rectal temperatures were measured, were not designed with a comparison group; therefore, no comparative analysis of the effect of sponge baths with another type of body hygiene was conducted in terms of thermal stability of PTI. The authors analyzed rectal temperatures before baths (baseline) and after in both studies. The difference between pre- and postbath temperatures was statistically significant. In E1, sponge baths for infants weighing less than 1,800 grams were performed inside incubators and for those above that weight were performed outside incubators; however, this variable showed no difference in rectal temperature after the bath. The minimum sample size of E1, considering a standard deviation of 0.4 and a significance level of $5 \%$, would be 61 newborns. The authors collected data from 79 infants and used McNemar's test to analyze temperatures before and after the baths; this test is suitable for analyzing frequencies in two related samples, such as in situations where before and after is analyzed. This test is also applicable to 
testing hypotheses. Therefore, the results can be considered reliable. In E4, which was conducted in the same neonatal health care facility as E1, the authors determined that the minimum sample size, considering a standard deviation of 0.5 and a significance level of $5 \%$, would be 24 newborns. The study sample was larger than that calculated with the parameters previously defined, with 49 newborns. In this study, the authors performed the analysis using McNemar's test and also evaluated for differences with Analysis of Variance (ANOVA) for the repeated measures of rectal temperature - before, during and after the sponge baths.

Study E2 was conducted with a sample of newborns with weights compatible with the extreme PTI (500 to 1,000 grams). However, the study design adopted is hierarchically inferior to E1 and E4. This study measured central and peripheral body temperature pre-and post-bath in the first and second weeks of life of newborns. The results showed a significant decrease in post-bath temperature compared to the measurements before bathing. Considering a standard deviation of 0.47 and a significance level of $5 \%$, the estimated minimum sample size would be 21 newborns (NB); the study sample was 26 NB.

In the study with a higher level of evidence (E3), the design was a randomized controlled trial which evaluated the stability of body temperature after baths in PTI undergoing sponge baths and immersion baths. The study was conducted in late PTI (35 to 36 completed weeks of gestation). The study sample consisted of 100 infants, randomized into control (sponge baths) and experimental (immersion bath) groups. Considering that the authors previously defined a standard deviation of 0.3 and a significance level of $5 \%$, the minimum estimated sample would be 35 infants. The data were analyzed using ANOVA. In the hierarchy of the methodological quality of the studies, which are the indicators that represent the reliability and validity of the studies, the clinical trial is at the top of the pyramid of evidence; superior to this design, are only studies of systematic reviews ${ }^{(14)}$. In this review, only one clinical trial on the effect of bathing in terms of thermal stability of PTI was identified. The choice for the design of a clinical trial crucially depends on the questions posed by the study, and the existence of two interventions, with a good option being a trial with two parallel groups ${ }^{(15)}$.

The physiology of PTI differs from that of full-term newborns and infants; the main differences are related to cardiorespiratory, neurological and thermoregulatory systems, among others. Due to physiological differences, certain routine procedures adopted in the neonatal unit can pose risks to PTI. The procedure of bathing becomes a challenge even for healthy full-term newborns, who need to maintain body temperature due to variation in heat loss through convection and evaporation mechanisms ${ }^{(5)}$.

Newborns with low birth weight, especially those weighing less than 1,000 grams, because of their anatomical and physiological characteristics, are more susceptible and vulnerable to cold stress because of the relationship be- tween surface area and body mass, absence of brown fat, absence of glycogen, the epidermis, the stratum corneum and a thinner dermis, lack of subcutaneous tissue, high concentration of body fluids and immature vasomotor control $^{(3)}$. PTI demonstrate failure to maintain body temperature, which can lead to complications such as hypoglycemia, respiratory distress and failure in the proper establishment of breastfeeding(16).

The monitoring of preterm infants with rectal temperature measurement is considered by many clinicians the gold standard of measurement because it closest to core temperature and is not impacted by environmental or age influences ${ }^{(9)}$. However, the measurement of rectal temperature is not a harmless procedure and can cause rectal trauma, and its accuracy has been questioned. Some of the studies included in this review measured rectal temperature; others, axillary (center) and sole (peripheral) temperature. In Brazilian neonatal units, axillary or tympanic temperature measurements are the most common; while the tympanic thermometer is used, doubt remains with respect to its accuracy ${ }^{(17)}$.

This review was limited to critical analysis of published studies that evaluated the effect/impact of baths on body temperature of PTI. It is not possible to advance to a metaanalysis, due to the impossibility of combining the results and analyzing them to verify the magnitude of loss in terms of risks from exposure to sponge baths, considering that in three of the studies (E1, E2 and E4), the sample profile of PTI was heterogeneous and the procedures were not uniform; additionally, the study designs differed among them.

Even though the issue of the studies analyzing sponge baths may be comparable, the interventions differed among the three studies, as described in table 1. Combining results of interventions that differed among studies can lead to erroneous conclusions in meta-analysis, suggesting that the body of evidence favors or disfavors the indications for intervention, when in fact the evidence is insufficient to draw definitive conclusions ${ }^{(18)}$. When deciding to conduct a meta-analysis, it is important to establish whether the questions of the studies are similar, with samples of similar individuals, and whether the methods used are similar ${ }^{(19)}$.

In summary, the studies analyzing sponge baths showed post-bath temperatures were lower, showing hypothermia, so the baths are not indicated for PTI. In turn, the only clinical trial (E3) that evaluated the effect of immersion baths in PTI had a larger sample than other studies that evaluated the effect of sponge baths. The findings in this trial showed that immersion baths promoted stabilization of body temperature; however, the sample consisted of late PTI, differing from the profile of $\mathrm{PTI}$ in the other studies.

\section{CONCLUSION}

The results of the analyzed studies showed that PTI undergoing sponge baths demonstrated lower body tempera-
Changes in physiological and behavioral parameters of preterm infants undergoing body hygiene: a systematic review Freitas $P$, Marques SR, Alves TB, Takahashi J, Kimura AF 
ture, inducing post-bath hypothermia, so these baths are not indicated as they destabilize the body temperature of PTI. Therefore, the respective indication should take into account individualized assessment and be adopted with caution.

\section{REFERENCES}

1. Brasil. Ministério da Saúde; Secretaria de Políticas de Saúde, Área da Saúde da Criança. Atenção humanizada ao recémnascido de baixo-peso: método canguru. 3a ed. Brasília; 2011.

2. Brasil. Ministério da Saúde. DATASUS. Sistema de Informações sobre Nascidos Vivos - SINASC [Internet]. Brasília; 2012 [citado 2012 dez. 12]. Disponível em: http://www2.datasus.gov. br/DATASUS/index.php?area $=0205$

3. Kimura AF, Oliva $C L$, Freitas $P$, Bueno $M$. Práticas favorecedoras do crescimento e do desenvolvimento: intervenções na UTI neonatal. In: Silva IA, Souza KV, Duarte ED, organizadoras. PROENF: Saúde materna e neonatal. Porto Alegre: Artmed; 2012. p. 97-126.

4. Knobel RB, Levy J, Katz L, Guenther B, Holditch-Davis D. A pilot study to examine maturation of body temperature control in preterm infants. J Obstet Gynecol Neonatal Nurs. 2013;42(5):562-74.

5. Loring C, Gregory K, Gargan B, LeBlanc V, Lundgren D, Reilly J, et al. Tub bathing improves thermoregulation of the late preterm infant. J Obstet Gynecol Neonatal Nurs. 2012;41(2):171-9.

6. Liaw JJ, Yang L, Chou HL, Yang MH, Cheo SC. Relationship between nurse caregiving behaviours during bathing: a preliminary study. J Clin Nurs. 2010;19(1-2):89-99.

7. Lunze K, Hamer DH. Thermal protection of the newborn in resource-limited environments. J Perinatol. 2012;32(5):317-324.

8. De-la-Torre-Ugarte-Guanilo MC, Takahashi RF, Bertolozzi MR. Systematic review: general notions. Rev Esc Enferm USP [Internet]. 2011 [cited 2014 May 9];45(5):1260-6. Available from: http://www.scielo.br/pdf/reeusp/v45n5/en_v45n5a33.pdf

9. The Joanna Briggs Institute. The JBI Approach. Grades of recommendation. Levels of Evidence [Internet]. Adelaide; 2014 [cited 2014 Apr 5]. Available from: http://joannabriggs.org/ jbi-approach.html\#tabbed-nav=Levels-of-Evidence

10. Mohler D, Liberati A, Tetzlaff J, Altman DG; PRISMA Group. Preferred reporting items for systematic reviews and meta-analyses: the PRISMA statement. J Clin Epidemiol. 2009;62(10):e1-34.
In regards to immersion baths, more studies qre needed to streghten their indication in clinical practice, since only one well-designed study has been identified in the literature and the sample was composed of late PTI.

11. Tapia-Rombo CA, Morales-Mora M, Alvarez-Vásquez E. Variations of vital signs, skin color, behavior and oxygen saturation in premature neonates after sponge bathing. Possible complications. Rev Invest Clin. 2003;55(4):438-43.

12. Montes Bueno T, de la Fuente Calle P, Iglesias Diz A, Bescos Calvo C, Quílez Cervera P, Madero Jarabo R, et al. Repercusión del aseo en la estabilidade térmica del recién nacido de extremado bajo peso durante las primeras dos semanas de vida. An Pediatr (Barc). 2005;63(1):5-13.

13. Tapia-Rombo CA, Mendoza-Cortés U, Uscanga-Carrasco $H$, Sánchez-García L, Tena-Reyes D, Lópes-Casillas EC. Variations of vital signs and peripheral oxygen saturation in critically ill preterm newborn, after sponge bath. Rev Invest Clin. 2012; 64(4):344-53.

14. Sackett DL, Straus SE, Richardson WS, Haynes BR. Evidencebased medicine: how to practice and teach EBM. 2nd ed. Edinburgh: Churchill Livingstone; 2000.

15. Machin D, Fayers PM. Randomized clinical trials: design, practice and reporting. San Francisco: Wiley-Blackwell; 2010. Design features; p. 23-39.

16. Darcy AE. Complications of the late preterm infant. J Perinatal Neonatal Nurs. 2009;23(1):78-86.

17. Smith J, Alcock G, Usher K. Temperature measurement in preterm and term neonate: a review of the literature. Neonatal Netw. 2013;32(1):16-25.

18. Higgins JPT, Green S editors. Cochrane handbook for systematic reviews of interventions, version 5.1.0, update March 2011 [Internet]. Quebec City: The Cochrane Collaboration; 2011 [cited 2014 May 9]. Available from: http:// handbook.cochrane.org/

19. Moore Z. Meta-analysis in context. J Clin Nurs. 2012;21(1920):2978-807. 